\title{
COSTLY POLLUTION ABATEMENT, COMPETITIVENESS, AND PLANT LOCATION DECISIONS
}

James R. Markusen

Working Paper 5490

\section{NATIONAL BUREAU OF ECONOMIC RESEARCH 1050 Massachusetts Avenue Cambridge, MA 02138 March 1996}

This paper was prepared for "Workshop 1995: Environmental Policy in Open Economies" held at the University of Konstanz, June 5-7, 1995, and "Workshop: Environmental Capital Flight" held at Wageningen University, September 13-15, 1995. The first draft was completed when the author was a visiting professor at the University of Konstanz during May and June of 1995. The author thanks the faculty and graduate students there for very stimulating discussions and for their great hospitality. This paper is part of NBER's research program in International Trade and Investment. Any opinions expressed are those of the author and not those of the National Bureau of Economic Research.

(ㄷ 1996 by James R. Markusen. All rights reserved. Short sections of text, not to exceed two paragraphs, may be quoted without explicit permission provided that full credit, including (C) notice, is given to the source. 


\title{
COSTLY POLLUTION ABATEMENT, COMPETITIVENESS, AND PLANT \\ LOCATION DECISIONS
}

\begin{abstract}
The US-Mexico free-trade debate included some theoretical assertions that were then used as arguments against trade and investment liberalization. (1) Trade liberalization increases the degree to which production is internationally relocated in response to environmental restrictions ("environmental dumping"?). (2) Investment liberalization, leading to multinational firms, similarly increases the production and welfare response to costly environmental restrictions. This paper adapts an oligopoly model, in which multinationals can arise endogenously, to examine these arguments. The findings are: (1) Trade liberalization increases production sensitivity to costly environmental restrictions, but arguments against liberal trade on welfare grounds do not follow. (2) Multinationals do not increase the production-reallocation effect caused by environmental restrictions or regulations. The inter-firm reallocation of production by competitive market forces in the absence of multinationals is slightly larger than the intra-firm reallocation when multinationals are present. In addition, the paper finds that the form taken by cost increases is crucial: restrictions that fall on fixed costs (e.g., more efficient burners and motors) have much smaller effects on production and welfare than restrictions that fall on marginal costs (e.g., cleaner fuels).

James R. Markusen

Department of Economics

University of Colorado

Boulder, CO 80309-0256

and NBER
\end{abstract}




\section{Introduction}

The recently completed North American Free Trade Agreement and the Uruguay round of the GATT brought to the public-policy arena a connection between trade policy and the environment. Environmental groups in the US made a number of anti-trade-liberalization arguments. One was that US multinationals would transfer production to Mexico in order to take advantage of lower environmental standards in Mexico if free trade were allowed. Attachment to this point of view was by no means universal. Several prominent US environmental groups supported free trade, arguing that a rising living standard in Mexico is the best long-run route to ensuring rising environmental protection in Mexico. Nevertheless, the anti-trade position caused enough of a stir to warrant further analysis.

The purpose of this paper is to conduct a positive analysis of the effects of environmental regulation on the location of plants, the volume of production (hence employment) and on national welfare. Insofar as "multinationals" are frequently fingered as the bad guys, the model will feature endogenous plant-location decisions by imperfectly competitive firms. I will focus here entirely on the costs imposed by regulation, without inquiring as to the benefits of a cleaner environment. The latter can be parameterized in almost any conceivable way, to make a given policy good or bad. The "welfare" effects of a policy should accordingly be interpreted as the worst possible outcome of that policy in which no environmental benefits are realized.

I will develop a standard oligopoly model with symmetric countries so as to avoid or "neutralize" any comparative-advantage basis for production specialization. ${ }^{2}$ There are two countries (home and foreign) and two goods ( $\mathrm{X}$ and $\mathrm{Y}$ ). $\mathrm{Y}$ is a competitive sector producing with constant returns to scale, and $\mathrm{X}$ is an imperfectly competitive sector producing with increasing returns and

\footnotetext{
${ }^{2}$ As an example, a regulation which raises costs in an industries will have welfare effects which depend crucially on whether that is an export or an import-competing industry. I wish to avoid such complications and the associated taxonomy of effects.
} 
imperfect competition. There are firm-specific as well as plant-specific fixed costs in $\mathrm{X}$, creating multi-plant economies of scale and a basis for multinational production.

There is free entry and exit into and out of four firm "types". National firms are single-plant firms. There are home country national firms, which may or may not export to the foreign country and similarly national firms in the foreign country. Multinational firms maintain plants in both countries and can similarly be located in the home or foreign country, "location" defined as the country in which the firm-specific capital is located.

It is very difficult to obtain analytical results in this model. Even a partial-equilibrium version is represented by 20 non-linear inequalities: eight output levels (home and foreign supplies for each of four firm types), eight markups, and four variables for the numbers of firms of each types. I thus analyze the model numerically using Rutherford's (1995) non-linear complementarity algorithm. ${ }^{3}$

Results are as follows. First, trade barriers do insulate production from the effects of environmental policy-induced cost increases in $\mathrm{X}$ in one country (foreign). Thus lowering trade barriers in the presence of these costs causes a larger fall in X production than would otherwise occur (recall that there is no comparative advantage). However, there is no second-best argument with respect to welfare. That is, the institution of trade barriers (or the decision not to remove them) following the institution of the environmental policy only lowers welfare further.

Second, the assertion that multinationals make production and plant locations more responsive to costs is not valid. Indeed, the opposite appears to be the case: multinationals smooth the effects of the cost increases in one country over both countries. Further analysis indicates that this finding is in turn largely due to the fact that multinationals arise in equilibrium when trade costs are relatively

\footnotetext{
${ }^{3}$ Rutherford has added two subsystems to GAMS. MILES (mixed inequality and non-linear equation solver) solves systems of non-linear inequalities. MPS/GE (mathematical programming system for general equilibrium) is a higher-level language for applied general-equilibrium modelling that calls MILES.
} 
high. Nevertheless, if multinationals are excluded by an investment ban at high trade costs, production and welfare have a slightly larger response to a given level of cost increase. The intuition that multinationals are adept at relocating production internationally ignores the fact that inter-firm reallocations among national firms through competitive market forces may be just as responsive.

Third, the form of cost increases is crucial in this type of oligopolistic environment. If cost increases fall on fixed costs (expensive fixed equipment), production and welfare effects are relatively minor. Some firms exit, with few consequences for either country. If cost increases fall on variable (marginal) costs, the effects on production and welfare are much larger.

Fourth, when the cost increase in country $f$ induces a regime shift, it is generally in the direction of national firms displacing multinational firms. Firms located in country h have an incentive to close plants in country $f$. Firms located in country $f$ only maintain plants in country $h$ if they would have done so anyway in the absence of the cost increase. Fifth, measured in terms of firm numbers, the cost increase in country $f$ shifts ownership of firms from country $f$ to country $h$ in most, but not in all cases. 


\section{Specification of the Model}

The underlying model is taken from Markusen and Venables (1995b). Two countries (h and f) produce two homogeneous goods, $\mathrm{Y}$ and $\mathrm{X}$. There are two factors of production, $\mathrm{L}$ (labor) and R. $\mathbf{L}$ is mobile between industries but internationally immobile. $\mathbf{R}$ is a specific factor used only in the $\mathrm{Y}$ industry. $\mathrm{R}$ acts partly to "convexify" the model. Expansion of the $\mathrm{X}$ sector draws labor from the $\mathrm{Y}$ sector, raising the $\mathrm{R} / \mathrm{L}$ ratio in the $\mathrm{Y}$ sector, thereby raising the cost of labor measured in terms of $\mathrm{Y}$. $\mathrm{Y}$ will be used as numeraire throughout the paper. Labor is used for both the fixed and the variable costs in producing $\mathrm{X}$ and in addition there are transport costs or other trade barriers between countries, specified as units of labor per unit of $\mathrm{X}$ exported. ${ }^{4}$

Subscripts $(i, j)$ will be used to denote the countries $(f, h)$. The output of $Y$ in country $i$ is a Cobb-Douglas function, where $\mathbf{R}_{\mathrm{i}}$ is country i's endowment of $\mathbf{R}$. The production function for $\mathbf{Y}$ is

$$
Y_{i}=L_{b y}^{*} R_{l}^{1-\alpha}, \quad i=h, f
$$

Labor demand in the $\mathrm{Y}$ sector is given by equality of the wage, $w_{i}$, to the value marginal product of labor,

$$
w_{i}=\alpha\left(L_{b} / R_{i}\right)^{\alpha-1}, \quad i=h, f
$$

Superscripts $(n, m)$ will be used to designate a variable as referring to national firms and

\footnotetext{
Throughout the paper, trade barriers will be modelled as things that consume real resources, such as transport costs, rather than as tariffs, which generate revenue for the importing country. The choice is made so as to avoid the interpretation of the results being confused by optimal tariff (termsof-trade) effects. For example, if in the presence of a production cost increase due to an environmental restriction we find that a small tariff improves welfare, is this due to the environmental restriction or to a terms-of-trade effect? The assumption I make avoids this confusion but does create the opposite bias: there is a presumption that trade barriers so define lower welfare. But this effect is very small in this model.
} 
multinational firms respectively. $\left(m_{i}, n_{i}\right)$ will also be used to indicate the number of active $m$ firms and $\mathbf{n}$ firms based in country $i$. Hopefully, it will always be clear from the context what is being represented (e.g., $n_{i}$ as a variable in an equation always refers to the number of national firms in country i).

$\mathrm{X}_{\mathrm{ij}}^{\mathrm{n}}$ denotes the sales in country $\mathrm{j}$ of a national firm based in country $\mathrm{i}$. A national firm undertakes all its production in its base country, so the labor used by one national firm in country $i$ is given by

$$
c_{i} X_{t}^{n}+\left(c_{i}+\tau\right) X_{j}^{n}+G_{i}+F_{p} \quad i, j=h, f, \quad i \neq j
$$

where $c_{i}$ is the constant marginal production cost and $G_{i}$ and $F_{i}$ are the plant-specific and firmspecific fixed costs both measured in units of labor. $\tau$ is the amount of labor needed to transport one unit of $\mathrm{X}$ from country $\mathrm{i}$ to country $\mathrm{j}$, which we assume to be the same in both directions, so $\tau$ is not subscripted by country.

A multinational based in country $i$ has sales in country $j, X_{i j}^{m}$. It operates one plant in each country, but incurs its firm specific fixed cost, $F_{i}$, in its base country. Sales are met entirely from local production not trade, so a country $\mathrm{i}$ multinational has demand for country $\mathrm{i}$ labor given by,

$$
c_{i} X_{i t}^{m}+G_{i}+F_{p} \quad i=h, f
$$

A country $\mathrm{i}$ multinational also has demand for country $\mathrm{j}$ labor,

$$
c_{j} X_{v}^{m}+G_{j} \quad \quad i, j=h, f
$$

Notice that we assume that the technology used by the MNE is determined by the location of its plants, not of its headquarters. In the next sections, we will raise $c_{f}$ or $G_{f}$ to represent the costs of 
6

meeting some environmental standard. These costs must be borne by all firms producing in country f, so they affect firms of type $n_{f}, m_{f}$, and $m_{h}$, but not type $n_{h}$ firms.

Let $\bar{L}_{\mathbf{i}}$ denote the total labor endowment of country $i$. Adding labor demand from $n_{i}$ national firms, $m_{i}$ multinationals based in country $i$, and $m_{j}$ multinationals based in country $j$, gives country $i$ factor market clearing:

$$
\begin{aligned}
\bar{L}_{i} & =L_{b j}+n_{i}\left(c_{i} X_{i j}^{n}+\left(c_{i}+\tau\right) X_{i j}^{n}+G_{i}+F_{i}\right) \\
& +m_{i}\left(c_{i} X_{i j}^{m}+G_{i}+F_{j}\right)+m_{j}\left(c_{i} X_{j i}^{m}+G_{j}\right)
\end{aligned}
$$

In equilibrium, the $X$ sector makes no profits so country $i$ income, denoted $M_{i}$, is

$$
M_{i}=w_{i} L_{i}+(1-\alpha) Y_{i} \quad i=h, f
$$

$\mathrm{p}_{\mathrm{i}}$ denotes the price of $\mathrm{X}$ in country $\mathrm{i}$, and $\mathrm{X}_{\mathrm{ic}}$ and $\mathrm{Y}_{\mathrm{ic}}$ denote the consumption of $\mathrm{X}$ and $\mathrm{Y}$. Utility of the representative consumer in each country is Cobb-Douglas,

$$
U_{i}=X_{i c}^{\beta} Y_{i c}^{1-\beta}, \quad X_{i c}=n_{i} X_{t i}^{n}+n_{j} X_{j}^{n}+m_{i} X_{i t}^{m}+m_{j} X_{j}^{m}
$$

giving demands

$$
X_{i c}=\beta M_{i} / p_{p} \quad Y_{k}=(1-\beta) M_{i}
$$

Equilibrium in the $\mathrm{X}$ sector is determined by pricing equations (marginal revenue equals marginal cost) and free-entry conditions. We denote proportional markups of price over marginal cost by $e_{i j}^{k},(k=n, m)$, so, for example, $e_{j i}^{m}$ is the markup of a country $j$ multinational in market $i$. Pricing equations of national and multinational firms in each market are (written in complementaryslackness form with associated variables in brackets): 
(10)

$$
p_{i}\left(1-e_{u}^{n}\right) \leq w_{i} c_{i} \quad\left(X_{u}^{n}\right)
$$

$$
p_{j}\left(1-e_{y}^{n}\right) \leq w_{i}\left(c_{i}+\tau\right) \quad\left(X_{v}^{n}\right)
$$

$$
p_{i}\left(1-e_{i i}^{m}\right) \leq w_{i} c_{i}
$$

$$
p_{j}\left(1-e_{i j}^{m}\right) \leq w_{j} c_{j} \quad\left(X_{\psi}^{m}\right)
$$

In a Cournot model with homogeneous products, the optimal markup formula is given by the firm's market share divided by the Marshallian price elasticity of demand in that market. In our model, the price elasticity is one (see equation (9)), reducing the firm's markup to its market share. This gives, (also using demand equations (9)),

$$
e_{v}^{k}=\frac{X_{v}^{k}}{X_{j c}}=\frac{p_{j} X_{i j}^{k}}{\beta M_{j}} \quad k=n, m, \quad i, j=h_{2}
$$

Using these expressions in pricing equations gives expressions for output in terms of price,

$$
X_{i l}^{n} \geq \beta M_{i} \frac{p_{i}-w_{i} c_{i}}{p_{i}^{2}}
$$

$$
X_{t}^{n} \geq \beta M_{j} \frac{p_{j}-w_{i}\left(c_{i}+\tau\right)}{p_{j}^{2}}
$$

$$
X_{i i}^{m} \geq \beta M_{i} \frac{p_{i}-w_{i} c_{i}}{p_{i}^{2}}
$$

$$
X_{v}^{m} \geq \beta M_{j} \frac{p_{j}-w_{f_{j}}}{p_{j}^{2}}
$$

Each of these holds with equality if the right hand side is positive, otherwise output equals zero. 
Note for reference later in the paper that equilibrium outputs per firm and hence the efficiency of production with increasing returns depends on prices and marginal costs $c_{i}$ but not directly on fixed costs. Changes in fixed costs will only indirectly affect production efficiency through changing the equilibrium values of $p_{i}$ and $w_{p}$

There are four zero-profit conditions corresponding to the numbers of the four firm types. Given equations (10)-(13), zero profits can be written as the requirement that markup revenues equal fixed costs.

$$
\begin{aligned}
& p_{h} e_{h k}^{n} X_{h}^{n}+p_{f} e_{h}^{n} X_{w}^{n} \leq w_{h}\left(G_{h}+F_{h}\right) \quad\left(n_{h}\right) \\
& p_{f} e_{f}^{n} X_{f}^{n}+p_{h} e_{f}^{n} X_{f n}^{n} \leq w_{f}\left(G_{f}+F_{f}\right) \\
& p_{h} e_{m}^{m} X_{h k}^{m}+p_{f} e_{W}^{m} X_{N}^{m} \leq w_{k}\left(G_{h}+F_{h}\right)+w_{f} G_{f} \quad\left(m_{h}\right) \\
& p_{f} e_{f}^{m} X_{f}^{m}+p_{k} e_{j}^{m} X_{f m}^{m} \leq w_{f}\left(G_{h}+F_{k}\right)+w_{h} G_{h} \quad\left(m_{f}\right)
\end{aligned}
$$

If outputs are positive, then using (14)-(18), these free entry conditions can be expressed as:

$$
\begin{aligned}
& \beta\left[M_{h}\left(\frac{p_{h}-w_{h} c_{h}}{p_{h}}\right)^{2}+M_{f}\left(\frac{p_{f}-w_{h}\left(c_{h}+\tau\right)}{p_{f}}\right)^{2}\right] \leq w_{h}\left(G_{h}+F_{h}\right) \\
& \beta\left[M_{h}\left(\frac{p_{h}-w_{f}\left(c_{f}+\tau\right)}{p_{h}}\right)^{2}+M_{f}\left(\frac{p_{f}-w_{f} c_{f}}{p_{f}}\right)^{2}\right] \leq w_{f}\left(G_{f}+F_{f}\right) \\
& \beta\left[M_{h}\left(\frac{p_{h}-w_{h} c_{h}}{p_{h}}\right)^{2}+M_{f}\left(\frac{p_{f}-w_{f} c_{f}}{p_{f}}\right)^{2}\right] \leq w_{h}\left(G_{h}+F_{h}\right)+w_{f} G_{f} \\
& \beta\left[M_{h}\left(\frac{p_{h}-w_{h} c_{h}}{p_{h}}\right)^{2}+M_{f}\left(\frac{p_{f}-w_{f} c_{f}}{p_{f}}\right)^{2}\right] \leq w_{f}\left(G_{f}+F_{f}\right)+w_{h} G_{h}
\end{aligned}
$$

Note for later reference that fixed costs are important in determining the number of firms of each type and whether or not a particular firm-type exists (is active) in equilibrium. 
To summarize the $\mathrm{X}$ sector in the model, the eight inequalities (15)-(18) are associated with the eight output levels (two each for four firm types), and the four inequalities in (23)-(26) are associated with the number of firms of each type. Additionally goods prices are given by (9), income levels from (7) and factor prices from factor market clearing equation (6) together with labor demand from the $Y$ sector, (2).

It is clear that even this minimal model is quite complicated, not only due to the number of endogenous variables, but due to the fact that it is inherently expressed in terms of inequalities. Some of these will be slack in equilibrium, and it is very difficult to make good progress with strictly analytical methods. In Markusen and Venables (1995b), we make considerable progress using partialequilibrium methods ( $w_{i}$ and $M_{i}$ held constant) on inequalities before turning to numerical methods. In this paper, I will move directly to numerical simulations. Interested readers are referred to Markusen and Venables (1995b) for a more in depth, analytical approach. 


\section{Environmental Requlations Impact on Marginal Cost}

This sections presents and interprets results for environmental policies which raise a firm's marginal production costs, such as requiring the use of more expensive low-sulphur oil or coal. Again, I emphasize that welfare "costs" are simply the loss of real income or utility ignoring any beneficial environmental effect from the regulation.

The model described in the previous section is solved in complementary slackness form using Rutherford's extensions to GAMS as noted earlier. In general, not all four firm types are active in equilibrium. Figure 1 presents results over a grid of proportional increases in marginal costs in country $f$ (the vertical axis) and trade costs (the horizontal axis). In the top row of Table 1 , the two countries are identical, with production in country $\mathrm{f}$ becoming more costly as we move down a column. In the bottom row, marginal costs are $60 \%$ higher in country $\mathrm{f}$ than in country $\mathrm{h}$. On the horizonal axis, the units are trade costs as a proportion of marginal costs in country $h$. These costs are symmetric in both directions.

Figure 1 presents qualitative results from the simulation, giving the equilibrium regime, where regime is defined as the firm types that are active in equilibrium. When transport costs are low (lefthand side of the diagram), the regime consists of only national firms $n_{h}$ and $n_{f}$ active and that regime is insensitive to the cost increase. When transport costs are very high, the regime is dominated by multinationals for all levels of cost increases. It is in the middle section (moderate transport costs) that we see regime shifts in response to cost increases. The most obvious effect as we move down a column (e.g., $\tau=.10$ ) is that type $m_{h}$ firms are replaced by type $n_{h}$ firms. This is intuitive: for a firm headquartered in country $h$, the cost increases in country $f$ create an incentive to close its plant in country $f$ and to serve country $f$ by exports from its plant in country $h$.

Firms headquartered in country $f$ continue to exist in equilibrium despite the cost increases, but their numbers are greatly diminished. In part their continued existence is a general-equilibrium 


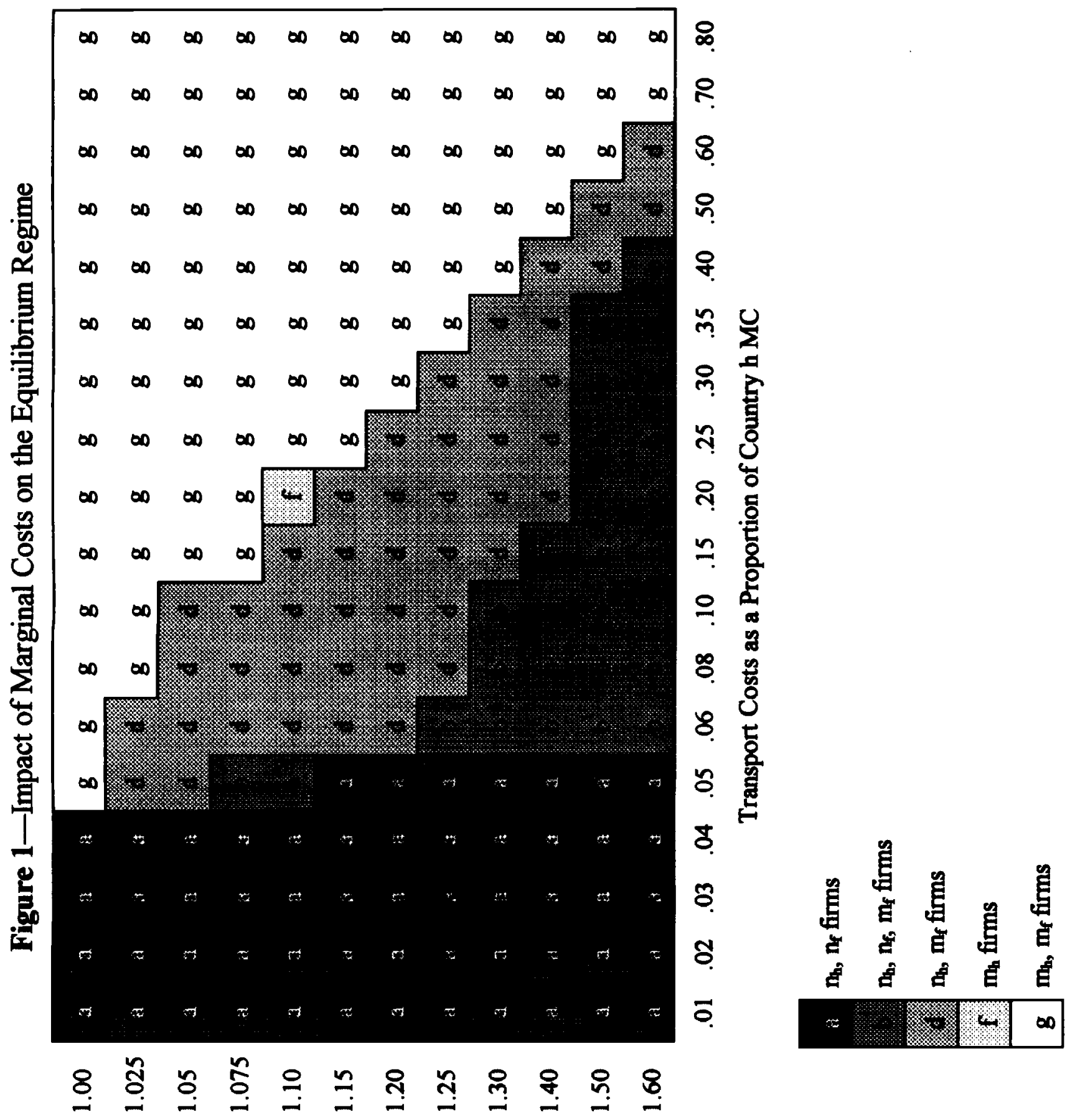

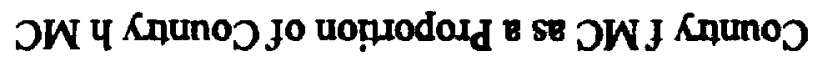


phenomenon. As some firms exit with cost increases, there is a moderation in the wage rate due to the reduced demand for labor in the $\mathrm{X}$ sector. ${ }^{5}$

One interesting result in terms of firm numbers occurs in the far right-hand columns of Figure $1(\tau=.70, .80)$. At all points in these columns, the number of type $m_{h}$ and type $m_{f}$ firms are identical, but each of them concentrates their production in their country $h$ plant. If production is dominated by multinationals, then marginal cost increases only affect plant-level production and not the number of firms in each country per se. With reference to inequalities (23)-(26), apparently prices adjust to the increase in $c_{f}$ to keep the solution to this subsystem constant. However, output per plant in country $f$ (inequalities (15)-(18)) is significantly reduced by the increase in $c_{f}$

Figures 2-4 illustrate the effects of the marginal cost increases on welfare and production levels $\left(U_{h}, U_{f}, X_{h}, X_{f}\right)$, where $X_{h}$ and $X_{f}$ include all production by all firm types producing in countries $h$ and $f$ respectively. These three Figures correspond to different columns of Figure $1, \tau$ $=.03, .20$, and .70 for Figures 2,3 , and 4 respectively.

Several results are apparent from Figures 2-4. First, the cost increases do have the intuitive effect of lowing production and welfare in country $f$ and raising those variables in country $h$. The effect on $\mathrm{X}$ production is much larger when trade costs are lower (Figure 2) than when they are higher (Figure 4). However, for a given cost increase, welfare is quite insensitive to the level of trade costs. Thus trade costs seem to protect $\mathrm{X}$ output from production cost increases, but not welfare. The intuition behind this result seems to run something like the following. When trade costs

\footnotetext{
${ }^{5} \mathrm{~A}$ somewhat puzzling result moving down column $\tau=.10$ of Figure 1 is that type-n firms exist in equilibrium as the cost increase becomes extreme. A detailed inspection of the results suggest that this is precisely the type of general-equilibrium effect just alluded to. The cost increases moving down the column $\tau=.10$ actually leads to a fall in $w_{f}$ as the number of type- $m_{f}$ firms falls rapidly: in part due to the cost increase and in part due to competition in the country-h market from increasing numbers of type- $n_{h}$ firms. Toward the bottom of this column, this general-equilibrium effect reducing $w_{f}$ is sufficiently strong that a very small number of type- $n_{f}$ firms can enter, serving only the domestic market. But, as intuition would suggest, the total number of plants in country $f$ and firms headquartered there falls monotonically as we move down any column of Figure 1.
} 

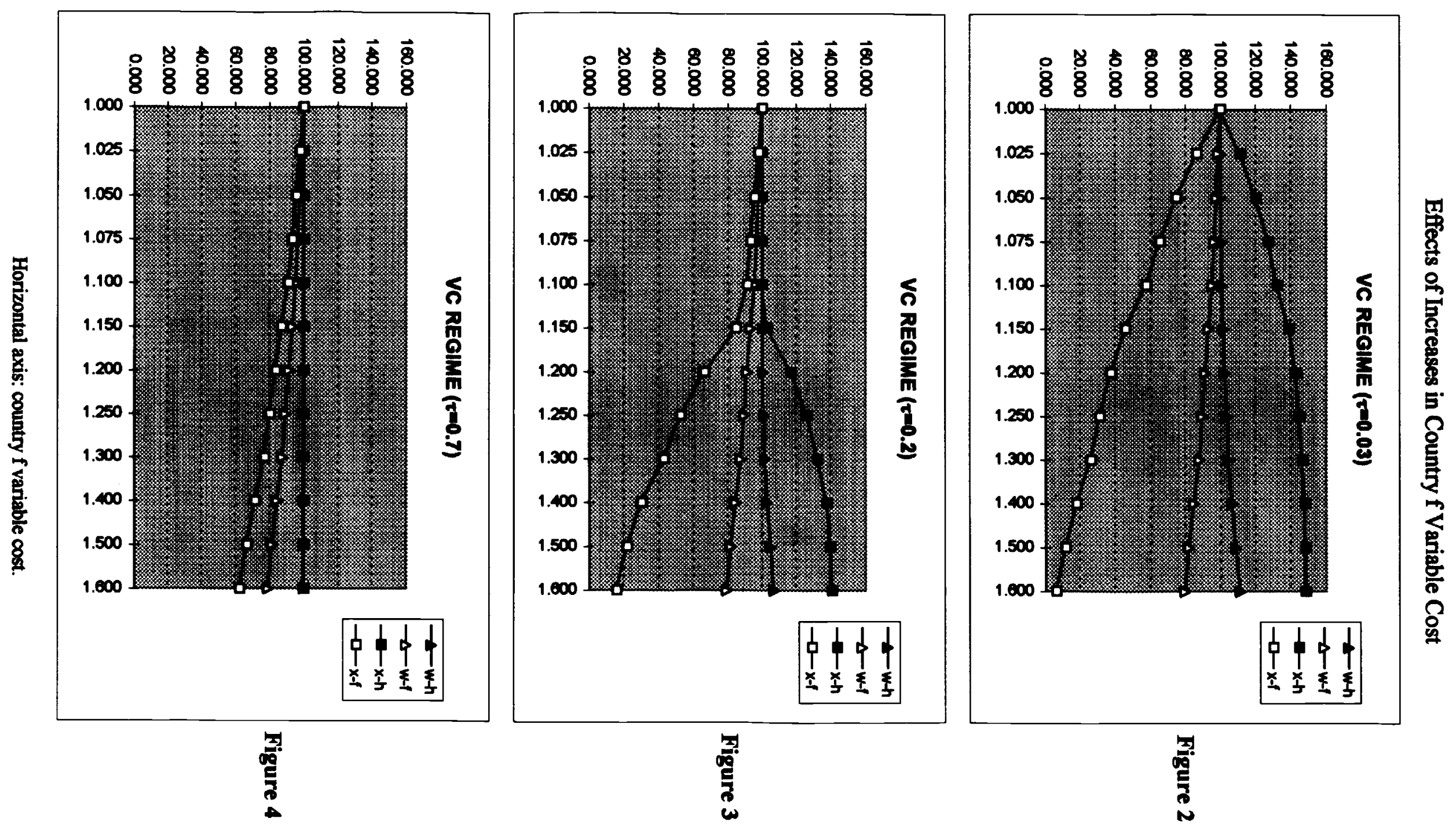
are very low, the production cost increase severely disadvantages the domestic $n_{f}$ firms in country $f$ who must complete against the low-cost $n_{h}$ producers in country $h$. There is a large loss of output due to the contraction of production in an increasing-returns sector, an effect with negative welfare consequences that has been emphasized often in the trade-industrial-organization literature. But consumer welfare losses in country $f$ are mitigated by the fact that there is only a very small change in the price of $\mathrm{X}$ due to the supply competition from country $\mathrm{h}$. With high trade costs, production in country $f$ is protected, implying the absence of the negative scale effect just mentioned. However, the cost of the environmental restriction results in a significantly higher price for consumers in country $f$, with negative welfare consequences. Thus trade costs protect production but not welfare. There does not seem to be a "second best" welfare argument to the effect that trade barriers should be increased in response to the production cost increase induced by the environmental regulation. ${ }^{6}$

The exception to the general results about production occurs for country $\mathrm{h}$ when production is dominated by multinationals at high trade costs (Figure 4). In this case, the cost increases in country $f$ have no effect at all on production and welfare in country $h$. Firms located in country $h$ receive no benefit from the cost increase in country $f$, but neither are they hurt by it: apparently that cost increase is fully passed on to country $f$ consumers.

Figures 2-4 give no credibility to the suggestion advanced in the introduction to the paper, that multinationals somehow lead to larger production responses to cost increases. I think that those advancing this suggestion are working with the intuition that multinationals are better able to relocate production internationally. What these analysts seem to be overlooking is that national firms face foreign national firms as competitors and hence when the former experience cost increases, production is transferred through the competitive market mechanism, not within the firm, but to

Of course, the optimal tariff argument remains with or without a regulation-induced cost increase as I noted earlier. 
national firms in the other country. There is no obvious reason why this competitive, market-driven reallocation among national firms should be weaker than intra-firm reallocation by multi-plant firms.

Figures $2-4$ in fact seem to support the opposite point of view, that production responses to cost increases are smaller when production is dominated by multinationals (Figure 4) that when it is dominated by national firms (Figure 2). However, this might not be due to the existence of multinationals per se, but rather to the fact that multinationals exist in equilibrium when trade costs are high. It is the underlying trade costs (the exogenous variable) that is insulating production from the cost increase rather than the (endogenous) existence of multi-plant firms? In order to examine this hypothesis, I rewrote the program suppressing multinational firms. Table 1 reports results for trade cost $\tau=.7$, the value of $\tau$ which creates the largest impact from banning multinationals. For lower values of $\tau$, multinationals are not that important and for higher values, countries are essentially in autarky so that national firms face little competition.

The first column in Table 1 gives the effects of a $60 \%$ increase in marginal cost in country f at $\tau=.7$ with multinationals permitted, the equilibrium regime being $m_{h}, m_{f}$ (Figure 1). The second column of Table 1 reports the changes when multinationals are banned both before and after the cost increase, the equilibrium regime being $n_{h}, n_{f}$. The welfare effects are exactly the same in the two column, and the production response is larger when multinationals are banned. Multinationals do somewhat smooth production effects (recall that $\tau$ is chosen to maximize this effect), but most of the apparent smoothing effect (Figure 2 versus Figure 4 ) is in fact due to the high trade costs that are associated with the multinational regime. The third column of Table 1 conducts an experiment in which the multinationals are banned after the cost increase. In other words, the initial unrestricted equilibrium (no cost increase, multinationals regime) is compared to one in which the cost is increased $60 \%$ and multinationals are banned. This experiment is addressing the question: if costs are increased, should multi-plant firms be banned as well? The answer is negative, or at least that banning multinationals has no beneficial effect. 


\section{Table 1}

Marginal cost in country $f$ increased by $60 \%, \tau=.7$ ( $\tau$ chosen to maximize the impact of banning MNEs) ${ }^{7}$

percentage changes (relative to zero increase)

MNES allowed

0.0

$-20.9$

0.0

$-37.5$
MNEs banned before and after cost increase
MNEs banned $^{8}$ after cost increase

Welfare $\mathbf{h}$

Welfare $\mathbf{f}$

$\mathbf{X}$ production $\mathbf{h}$

$X$ production $\mathbf{f}$

0.0

$-20.9$

8.1

$-45.9$
$-0.5$

$-21.3$

6.9

$-46.5$

\section{Table 2}

Plant fixed cost increased by equivalent of $60 \%, \tau=.3$

( $\tau$ chosen to maximize the impact of banning MNEs)

percentage changes (relative to zero increase)

MNEs allowed $\quad$ MNEs banned

before and after after cost

cost increase increase

$\begin{array}{lrrr}\text { Welfare h } & -0.5 & 0.0 & -0.5 \\ \text { Welfare f } & -8.0 & -8.0 & -8.5 \\ \text { X production h } & -1.1 & 1.8 & 0.6 \\ \text { X production f } & -15.5 & -17.2 & -18.1\end{array}$

By this I mean that the value of $\tau$ is chosen (among the values reported in Figures 1 and 2) such as to make the difference between columns 1 and 2 in Tables 1 and 2 as large as possible.

${ }^{8}$ This column compares the value of variables after the cost increase and with MNEs banned, to an initial situation with no cost increase and MNEs permitted. 


\section{Environmental Requlations Impact on Plant Fixed Costs}

In this section we assume that the environmental regulation impacts on plant fixed costs, such as requiring expensive equipment, but has no effect on marginal costs. I have a hard time thinking of a perfect example in production technologies, but electronic fuel injection in automobiles is an example of a fixed cost improvement that likely actually lowers marginal costs through improved fuel economy.

There are conceptual difficulties in picking values of fixed cost increases that are comparable to the values of marginal cost increases used in the previous section. First, plant fixed costs are small compared to variable costs in the calibration of the model, so that the same percentage increase in fixed costs penalizes the firm much less than the same percentage increase in variable costs. This is taken care of by multiplying up the percentage increase in fixed costs so that the total cost to the firm is the same in the present case as the total cost imposed by the regulation impacting on variable cost. The second difficulty is that the multiple necessary to equate the two is not constant, but varies according to the degree of the cost increase. Firms respond to the increase in variable costs by reducing output, thus costs do not increase in proportion to the cost factor. General equilibrium effects complicate the comparison further, as does the initial regime. A variable cost increase impacts a type $n_{f}$ firm (serving $h$ by exports) more than it does a type $m_{f}$ firm (serving $h$ by production in $h$ ).

What I have done is the following. Compute the variable cost case given a cost increase of $2.5 \%$ and assuming a value of $\tau$ such that multinationals dominate in equilibrium (with reference to Figure 1, this implies a value of $\tau$ greater than or equal to .08). Take the resulting total cost increase an calculate the increase in plant fixed costs necessary to duplicate this increase in variable costs. An increase of $2.5 \%$ in variable cost turns out to be duplicated by an increase in plant fixed costs of $34 \%$. I then use the ratio between these two (13.6) to inflate the percentage increases on the vertical axis of Figure 1 to arrive at percentage increases in $G_{f}$ use to calculate Figures 5-8. However, $I$ have left 
the labeling of Figures 5-8 the same as in Figures 1-4 in order to facilitate an easier cross reference.

The equilibrium regime as a function of the cost increase in $G_{f}$ and the trade cost is shown in Figure 5. There are a few qualitative similarities between this diagram and Figure 1. National firms dominate at low values of the $\tau$, but the picture at moderate to high levels of $\tau$ is rather different. At high levels of $\tau$ and cost increases greater than (the fixed-cost equivalent of) $7.5 \%$, the regime consists of types $m_{h}$ and $n_{h}$ firms active in equilibrium. At moderate levels of $\tau$, types $m_{f}$ and $n_{h}$ firms are active in equilibrium.

The fact that type- $n_{h}$ firms enter as a result of an increase in $G_{f}$ is intuitive. The higher plantspecific fixed costs in country $f$ disadvantage all firm types with plants located in country $f$, and thus create an advantage for type- $n_{h}$ firms. The fact that production does continue to take place in country $f$ is the result of the general-equilibrium effect operating through wages noted in the previous section: the exit of some plants in country $f$ due to the cost increase lowers $w_{f}$ permitting some plants to survive.

The fact that it is type- $m_{f}$ firm at moderate trade costs and type- $m_{h}$ firms at high trade costs producing in country $\mathrm{f}$ seems to be another subtle general-equilibrium effect operating through both countries' wage rates. If a firm is going to be a multinational in the model, the location of its firmspecific capital depends only on which country has the lower wage rate (note that, from (25) and (26) that $m_{h}$ and $m_{f}$ can both be positive only if $w_{h}=w_{\partial}$. When trade costs are moderate, type- $n_{h}$ firms are dominant, raising the wage rate in country $h$ above that in country $f$, making it optimal for any firm that is a multinational to be a type- $m_{f}$ multinational. But very high trade costs penalize type- $n_{h}$ firms, reducing their numbers and the demand for labor and wage rate in country $h$. This makes it optimal for multinationals to be headquartered in country h. At high $\tau$, the equilibrium labor demanded for firm-specific costs in country $h$ does not outweigh the increased labor demand due to high plant-specific costs in country $\mathrm{f}$. 
Figure 5-Impact of Plant Fixed Cost on the Equilibrium Regime
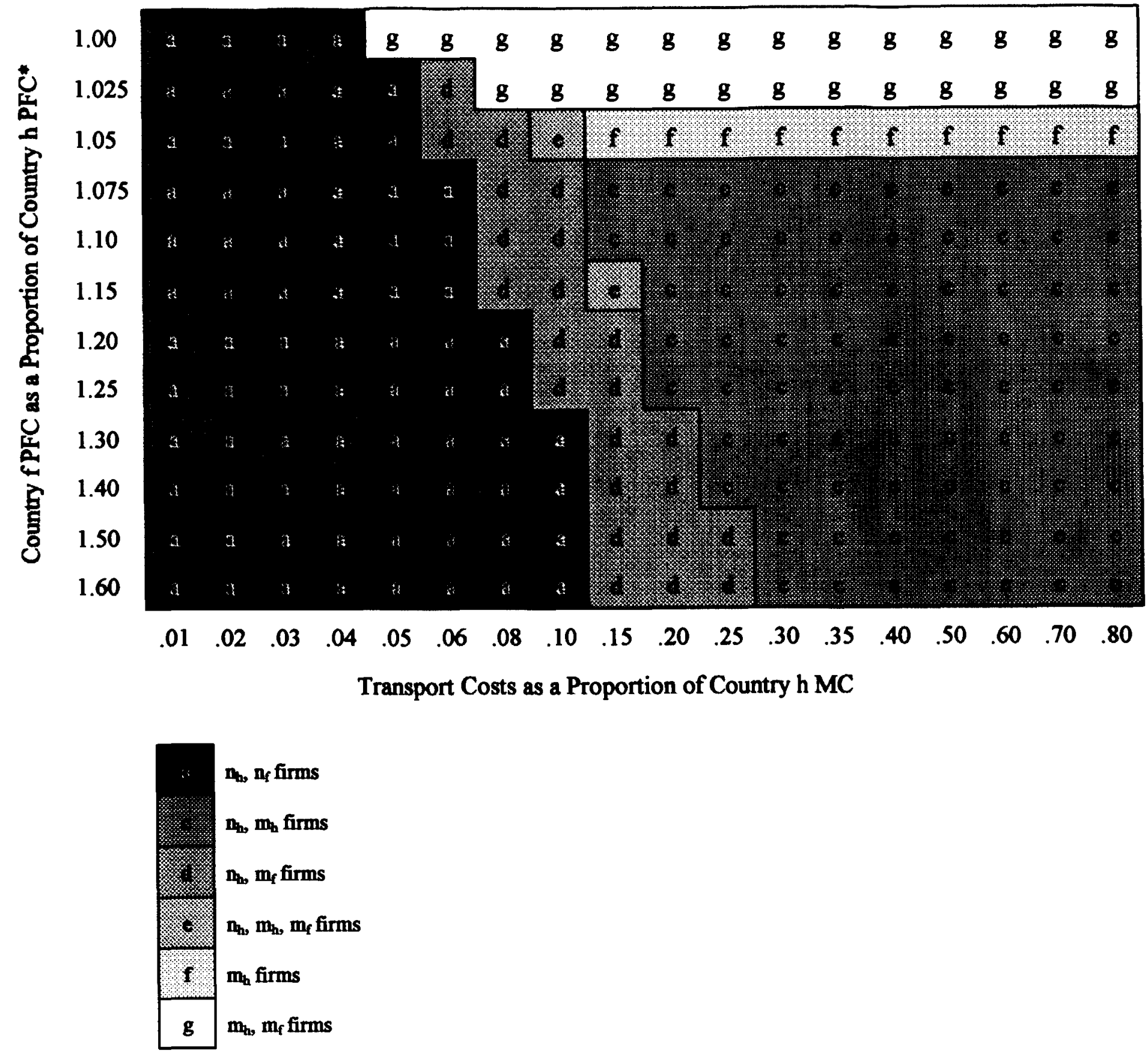
Figures 6-8 present the same graphs as Figures $2-4$, graphing changes in $U_{h}, U_{f}, X_{h}$, and $X_{f}$, against the level of the cost increase. We see qualitatively similar results for the two sets of Figures. Moving from Figure 6 to Figure 8, we again see the result that trade costs insulate production from the cost increase, but they do not insulate welfare. Trade costs protect domestic production, but force consumers to buy the costly domestic output instead of cheap foreign imports.

In comparing Figures $2-4$ and 5-8, we see however a quantitatively different effect. Both the production and welfare effects are much smaller in the fixed cost case than in the variable cost case. The intuition is something like the following. In the case of a regulation impacting on variable costs, significant costs can be avoided only by producing a lot less. Not only is output affected, but welfare is as well since the lower output still requires a large input of labor (i.e., real labor productivity falls), and there is the loss of the surplus of price over marginal cost on the lost output, the efficiency effect emphasized in the trade-industrial-organization literature.

In the case of a regulation impacting on fixed costs, significant cost increases can essentially be avoided for the industry as a whole by the exit of some firms, with the remaining firms producing larger outputs. This is what happens in this model. For example, at the lower right-hand corner of Figure 1, there 11.5 firms maintaining plants in country f. In Figure 5, there are 4.4 firms maintaining plants in country f. Yet in the latter case, the total output of these fewer firms is $35 \%$ higher than in the variable cost case. Output per plant in country $f$ is then $91 \%$ higher in the fixed cost case than in the variable cost case. In the fixed-cost case, the industry is able to effectively rationalize through market mechanisms by having a smaller number of plants producing larger output per plant. ${ }^{9}$

I should emphasize that this exercise considers an increase in a "pure" fixed cost. That is, the cost is independent of the scale of the plant or plant capacity. Indeed, in this model there is no limit to plant capacity, average cost falls continuously and is asymptotic to marginal cost. The empirical relevance of this may be limited. In many cases, the cost of fixed equipment may be related to the scale of plant operation (e.g., sulphur scrubbers), creating a situation that is actually a hybrid of our two pure cases. 
Effects of Increases in Country $f$ Plant Fixed Cost

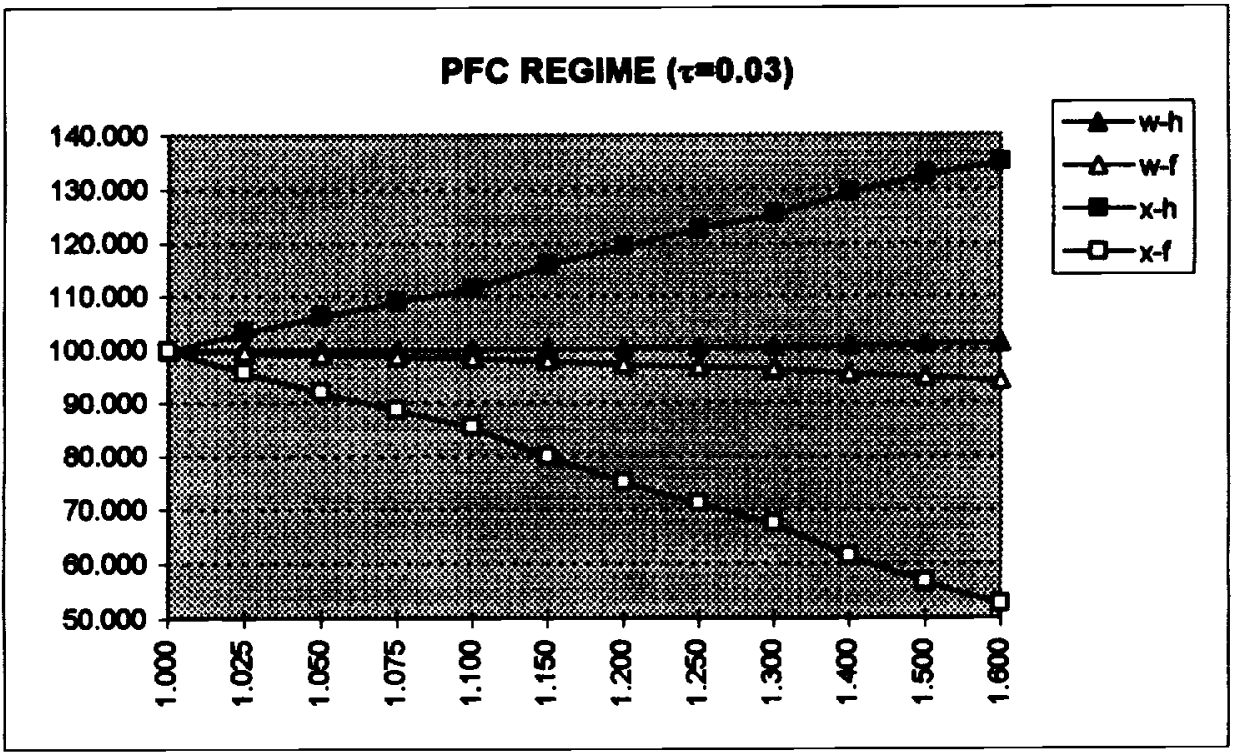

Figure 6

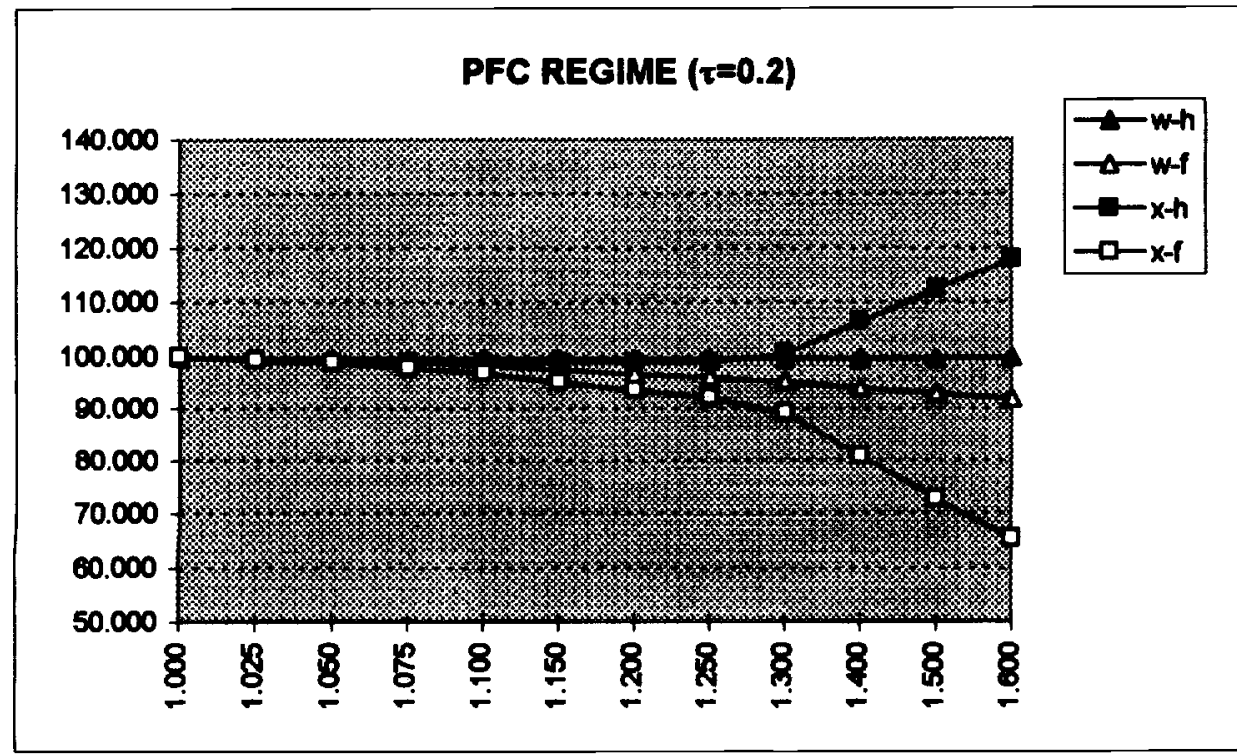

Figure 7

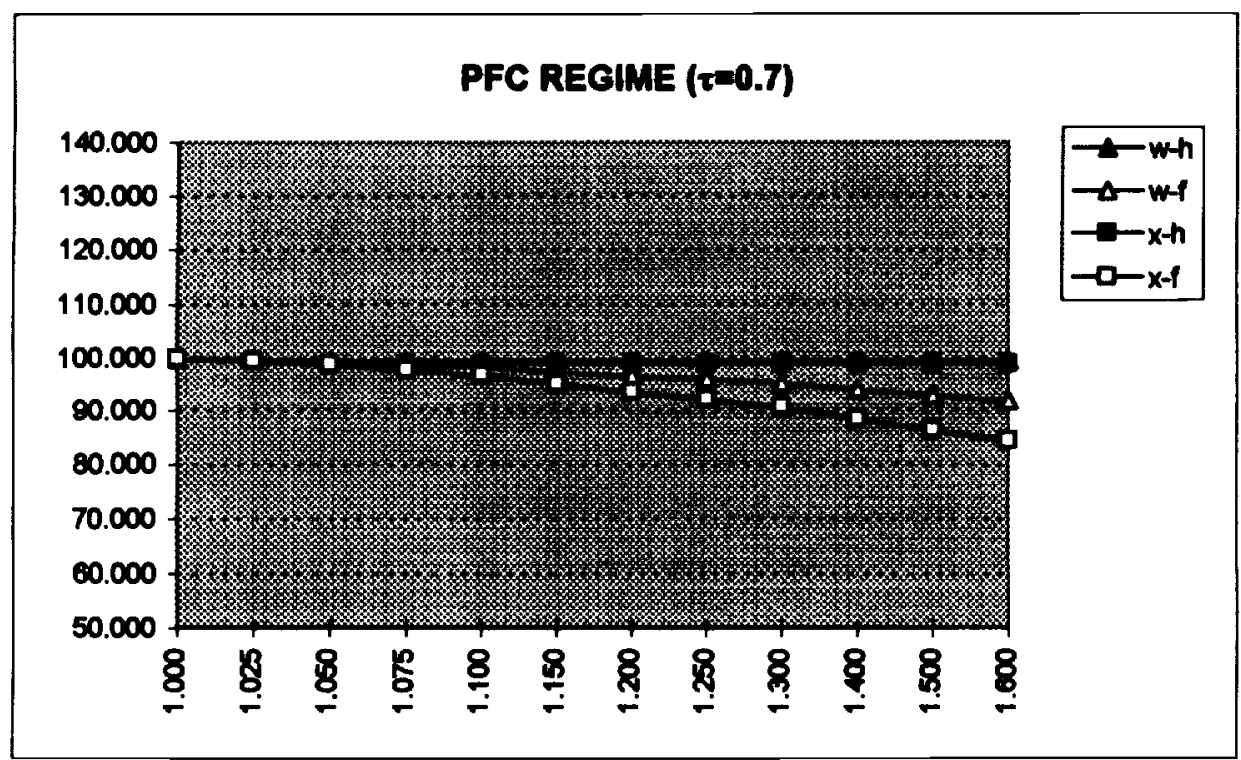

Figure 8

Horizontal axis: country $f$ plant fixed cost (see text). 
Table 2 shows results qualitatively similar to those of Table 1. The fact that production is insulated more from the increase in plant fixed costs when the regime is dominated by multinationals really has little to do with multinationals per se, but rather with the existence of high trade costs which support the multinationals as the equilibrium regime. A comparison of the first and second columns of Table 2 indicate that suppressing (banning) multinationals generates only a slightly larger fall in $\mathrm{X}$ production in country $\mathrm{f}$ and rise in country $\mathrm{h}$. Column three of Table 2 emphasizes that a combined policy of instituting the environmental regulation and then banning multinationals makes no sense. 


\section{Summary and Conclusions}

This paper is motivated by several arguments that were advanced during the debate on USCanada-Mexico free trade. The general thrust of these arguments was that there is a conflict between free trade and environmental quality. Specifically, the suggestion was made that free trade would cause US multinationals to move production to Mexico in order to avoid costly US environmental controls, thereby causing a loss in US jobs and welfare. This view seems to suggest two separate propositions. First, trade barriers must insulate domestic production and welfare from the effects of costly environmental regulation if their removal has these asserted effects. Second, multinationals are easily capable of shifting production internationally, exaggerating the effects of policies relative to a situation where there are no multinationals.

We find that trade barriers do indeed insulate production from the cost increases due to environmental regulation, but they do not insulate welfare. Insulating production has a favorable effect in this increasing-returns model due to the excess of price over marginal cost, but it also has an unfavorable effect on consumers through higher prices. In our simulations, these effects are almost exactly offsetting. Thus there is no second-best argument to the effect that production cost increases should be accompanied by trade barriers.

Results show no support for the argument pertaining to multinationals being adept at shifting production internationally relative to a case where they are banned (only single-plant national firms are permitted). In fact, the opposed appears to be the case. Changes in national production following a cost change are much smaller when production is dominated by multinationals than when it is dominated by national firms. However, we then showed that this is largely due to the fact that multinationals arise in equilibrium when trade costs are high. Most of the apparent smoothing effect is in fact due to high trade costs, as we showed by recomputing some solutions with type $\mathbf{m}_{\mathbf{h}}$ and $\mathbf{m}_{\mathbf{f}}$ suppressed. But the argument that multinationals increase production responses is rejected. In the 
absence of multinationals, the competitive market mechanism leads to slightly larger production shifts than does the internal cost minimization mechanism in the presence of multinationals.

Next, we noted that the form of regulation-induced cost increases was quantitatively very important in the model. Regulations which impact on plant fixed cost are relatively easily absorbed by the exit of some firms, and higher outputs by the remaining firms. Regulations which impact on marginal costs cannot be absorbed except by production decreases, resulting in larger welfare effects in addition to larger production effects.

Finally, there are some general results about firm types and ownership, although I am not sure of their policy importance. (A) In general, environmental cost increases shift the regime (when they do so at all) away from multinational firms toward national firms. In particular, firms headquartered in country h have an incentive to shut plants in country f. (B) In general, firm ownership shifts from country $f$ to country $h$ even though firm-specific fixed costs (the location of which is the definition of ownership) are not directly affected. This last result may be important insofar as emotional value is sometime attached to national ownership. It could also be of substantial importance in a model with local R\&D spillovers from headquarters activities. 


\section{References}

(includes references to some related work not discussed in the text)

Anderson, Kym and Richard Blackhurst (1994), The Greening of World Trade Issues, Ann Arbor: University of Michigan Press.

Barrett, Scott (1993), "Strategic Environmental Policy and International Trade", Journal of Public Economics, forthcoming.

Bhagwati, Jagdish and T.N. Srinivasan, "Trade and the Environment: Does Environmental Diversity Detract from the Case for Free Trade?", working paper.

Brainard, S. Lael (1992), "A Simple Theory of Multinational Corporations and Trade with a Trade-off between Proximity and Concentration", MTT and NBER working paper.

Copeland, Brian R. (1991), "Taxes versus Standards to Control Pollution in Imperfectly Competitive Markets:, mimeo, presented at the Canadian Resource and Environmental Economics Study Group Annual Meeting, Guelph, Ontario, September 1991.

Levinson, Arik (1994), "Environmental Regulations and Industry Location: International and Domestic Evidencen, working paper.

Markusen, James R. (1995), "Incorporating the Multinational Enterprise into the Theory of International Trade", Journal of Economic Perspectives 9, 169-189.

Markusen, James R., Morey, Edward R. and Nancy Olewiler (1993), "Environmental Policy When Market Structure and Plant Locations are Endogenous", Journal of Environmental Economics and Management 24, 69-86.

Markusen, James R., Morey, Edward R. and Nancy Olewiler (1995), "Competition in Regional Environmental Policies when Plant Locations are Endogenous", Joumal of Public Economics 56, 55-77.

Markusen, James R. and Anthony J. Venables (1995a), "The Increased Importance of Direct Investment in North Atlantic Economic Relationships: A Convergence Hypothesis", in Canzoneri, Matthew, Wilfred Ethier and Vittorio Grilli (editors), The New Transatlantic Economy London: Cambridge University Press, forthcoming.

Markusen, James R. and Anthony J. Venables (1995b), "Multinational Firms and the New Trade Theory", National Bureau of Economic Research Working Paper number 5036.

Rauscher, Michael (1991), "Foreign Trade and the Environment", in Horst Siebert (editor), Environmental Scarcity: The International Dimension, Tubingen: J.C.B. Mohr.

Rauscher, Michael (1994), " Environmental Regulation and the Location of Polluting Industries", working paper. 
Rutherford, Thomas F. (1995), "Applied General-Equilibrium Modelling with MPS/GE as a GAMS Subsystem".

Rutherford, Thomas F. (1995), "Carbon Dioxide Emission Restrictions in the Global Economy: Leakage, Competitiveness, and the Implications for Policy Design, University of Colorado Working Paper.

Ulph, Alastair (1994), Environmental Policy, Plant Location and Government Protection", in C. Carraro (editor), Trade, Innovation, and the Environment, Kluwer.

Venables, A. J. (1985), "Trade and trade policy with imperfect competition; the case of identical products and free entry", Journal of International Economics, 19, 1-19. 